\title{
Structure Property Correlation of Thin Wall Ductile Iron
}

\author{
Rajat Upadhyaya ${ }^{1} \&$ Kamlesh Kumar Singh ${ }^{1}$ \\ ${ }^{1}$ Foundry Technology Department, National Institute of Foundry and Forge Technology, Hatia, India \\ Correspondence: Rajat Upadhyaya, Foundry Technology Department, National Institute of Foundry and Forge \\ Technology, Hatia, India. E-mail: vishalakshiphd@gmail.com
}

Received: October 18, 2018

Accepted: October 31, 2018

Online Published: November 14, 2018

doi: $10.5539 /$ jmsr.v8n1p1

URL: https://doi.org/10.5539/jmsr.v8n1p1

\begin{abstract}
This research work concerns an assessment of the effect of one step inoculation method on thin section castings (2-5) $\mathrm{mm}$ analyzed. In this study inoculants representing $\mathrm{Ce}, \mathrm{Zr}$ and $\mathrm{Sr}$ bearing $\mathrm{Fe}-\mathrm{Si}$ alloys were used. It has been observed that section thickness of $2 \mathrm{~mm}$ thin plate containing Ce bearing Fe-Si alloys at $0.4 \mathrm{wt} \%$ contain mainly pearlitic matrix having microhardness (HV20), ultimate tensile strength (UTS) and percentage of elongation are $272 \mathrm{HV}, 720 \mathrm{MPa}$ and $4.5 \%$ respectively. It was observed that wear of $2 \mathrm{~mm}$ section thickness of thin plate containing Ce bearing Fe-Si alloys have greater wear resistance (272HV) compare to $\mathrm{Zr}$ bearing Fe-Si alloys $(262 \mathrm{HV})$ and Sr bearing Fe-Si alloys $(259 \mathrm{HV})$ respectively at $0.4 \mathrm{wt} \%$ due to reason of pearlitic and ferritic volume fraction contents present in matrix.
\end{abstract}

Keywords: Thin wall ductile iron, In-mould inoculation, Ultimate tensile strength, Micro hardness

\section{Introduction}

Unlike gray iron whose production tends to stagnate, ductile iron enjoy growth exceeding 3\% per year (Karsay, 1965). In the recent years basically interest on minimizing the weight of casting components and increasing the mechanical properties. This motivates automobile manufacturers to decrease the weight of automobile leads in the 1970's by reducing the thickness of steel sheets (Mampaey, \& Xu, 1997; Yeunga, \& Leea, 1998; Ruxanda, Stefanescu, \& Piwonka, 2002; David, Mossone, Boeri, \& Sikora, 2009). Inoculation process is essential for cast iron structure. It also eliminates carbides formation into thin parts, refine the structure and promotes more graphite formation for solidification (Banerjee, \& Stefanescu, 1991). Various studies analysed the separate and combined effects of $\mathrm{Ce}$ (cerium) and $\mathrm{La}$ (Lanthanum) on the microstructure evolution and graphite morphology and they also found that $\mathrm{La}$ (Lanthanum) either alone or in combination with Ce (cerium) has a detrimental effect on nodule count and significant amount of carbide is formed in $\mathrm{La}$ (Lanthanum) containing iron whereas $\mathrm{Ce}$ (cerium) results in a significant drop in the extension of carbide zone (Woolley, \& Stefanescu, 2005; Dix, Ruxanda, Torrance, Fukumato, \& Stefanescu, 2003; Chisamera, Riposan, Stan, Toboc, Skaland, \&White, 2013; Olsen, \& Skaland, 2004). Skaland (2001) proposed that carbon diffusion towards nuclei centre may due to formation of cerium-calcium- sulphides and oxides increases the nodule count of Ce containing inoculants. Choi, Kim, Choi, Kimb, and Rohatgi (2004) have reported that the rare earth (RE) elements are helpful in reducing chill and influencing the formation of ferrite. Riposan, Chisamera, Uta, Stan, Naro, and Williams (2014) have investigated that the addition of rare earth elements during in-mould inoculation provides control of casting hardness and improve graphite quality. Ochulor, Adeosun, Amuda, and Balogun (2015) found that two step inoculation methods provide better nodule count and nodularity with 2,3 and $4 \mathrm{~mm}$ thin plate thickness respectively. Upadhyaya, Singh, and Kumar (2017) proposed that Ce bearing Fe-Si alloy at $0.4 \%$ reducing under-cooling to improve nodularility and nodule count in thin plate casting thickness. In this paper previous studies have not been reported the methodology of one step inoculation method. The present work concerns an assessment of representing three types of potent inoculants containing $\mathrm{Ce}, \mathrm{Zr}$ and $\mathrm{Sr}$ bearing Fe-Si alloy at an addition rate of $0.2 \mathrm{wt} \%, 0.4 \mathrm{wt} \%$ and $0.6 \mathrm{wt} \%$ of one step inoculation method. It can be seen that Ce bearing Fe-Si alloy at $0.4 \mathrm{wt} \%$ provides better mechanical properties, nodule count, nodularity $(>90 \%)$ and nodule size distribution as compare to $\mathrm{Zr}$ bearing Fe-Si alloys and $\mathrm{Sr}$ bearing Fe-Si alloys. 


\section{Experimental Procedures}

Melting of SG (Spheroidal graphitic) Iron heat was taken out in a coreless induction furnace of 1 ton capacity. The tapping temperature of liquid metal from furnace to preheated ladle at $1430^{\circ} \mathrm{C}-1460^{\circ} \mathrm{C}$. The final charge metal composition is shown in Table 1.

Table 1. Final charge metal composition (in percentage)

\begin{tabular}{rrrrrr}
\hline $\mathrm{C}$ & $\mathrm{Si}$ & $\mathrm{Mn}$ & $\mathrm{P}$ & $\mathrm{S}$ & $\mathrm{Cr}$ \\
\hline 3.65 & 2.53 & & 0.330 .093 & 0.014 & 0.045 \\
\hline
\end{tabular}

Sandwich method has been done for magnesium treatment. The composition of nodulization treatment alloys are summarized in Table 2.

Table 2. Nodulization treatment $\mathrm{FeSi}$ (7-8\%) Mg alloy composition (in percentage)

\begin{tabular}{|c|c|c|c|}
\hline $\mathrm{Mg}$ & TRE & $\mathrm{Al} \quad \mathrm{Si}$ & $\mathrm{Fe}$ \\
\hline $7-81.2-1.4$ & $1.3-1.6$ & $1.3 \max 45-49$ & $\mathrm{Bal}$ \\
\hline
\end{tabular}

This preheated pouring ladle has been used for tapping molten metal from an inductance furnace and rapidly poured into magnesium treated ladle. The magnesium treated melt has been directly poured into mould cavity in addition rate of $0.2 \mathrm{wt} \%, 0.4 \mathrm{wt} \%$ and $0.6 \mathrm{wt} \%$ one step in mould inoculation. The thin plate section thickness (2-5) $\mathrm{mm}$ of ductile iron castings have been shown in Figure 1. Table 3 enlist the composition of inoculants.

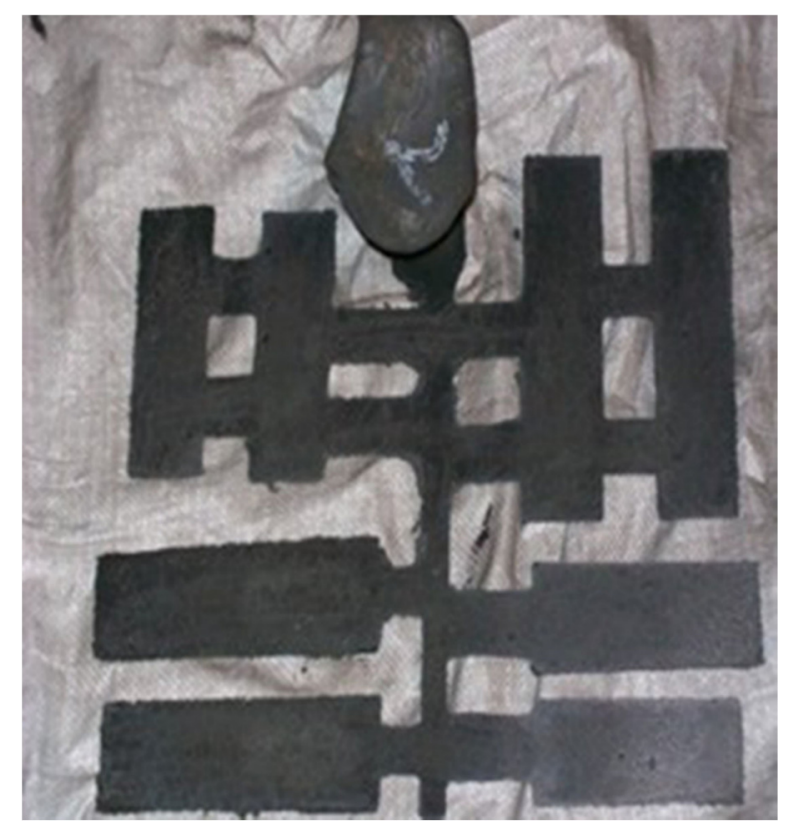

Figure 1. Thin Plate Ductile Iron Casting

Table 3. Inoculants composition used in thin wall ductile iron casting (in percentage)

\begin{tabular}{|c|c|c|c|c|c|c|c|c|c|c|c|}
\hline Inoculants & $\mathrm{Si}$ & $\mathrm{Zr}$ & $\mathrm{Ba}$ & $\mathrm{Ce}$ & $\mathrm{Mn}$ & $\mathrm{Sr}$ & $\mathrm{Ca}$ & $\mathrm{Al}$ & $\mathrm{S}$ & $\mathrm{O}$ & $\mathrm{Fe}$ \\
\hline $\begin{array}{l}\text { Ce bearing } \\
\mathrm{Fe}-\mathrm{Si} \text { alloy }\end{array}$ & $70-80$ & nil & Nil & $1.5-2.5$ & nil & nil & $1.5-2.5$ & $1 \max$ & less than 1 & less than 1 & bal \\
\hline $\begin{array}{l}\mathrm{Zr} \text { bearing } \\
\mathrm{Fe}-\mathrm{Si} \text { alloy }\end{array}$ & $60-70$ & $3.5-4.5$ & $0.2-0.6$ & nil & $3-5$ & nil & $0.5-1.8$ & $0.65-1.5$ & nil & nil & bal \\
\hline $\begin{array}{l}\text { Sr bearing } \\
\text { Fe-Si alloy }\end{array}$ & $70-80$ & nil & Nil & nil & nil & $0.5-1.5$ & $0.50 \max$ & $0.10 \max$ & nil & nil & bal \\
\hline
\end{tabular}




\section{Results and Discussion}

\subsection{Microscopic Observation}

The $2 \mathrm{~mm}$ section thickness microstrutre inoculated by Ce bearing Fe-Si alloy has been shown in Figure 2. It has been observed that $\mathrm{wt} \%$ of one step in mould inoculation incresases $0.2 \%$ to $0.4 \%$ pearlitic matrix has been formed while $\mathrm{wt} \%$ was $0.6 \%$, the matrix has been changed to pearlitic to ferritic

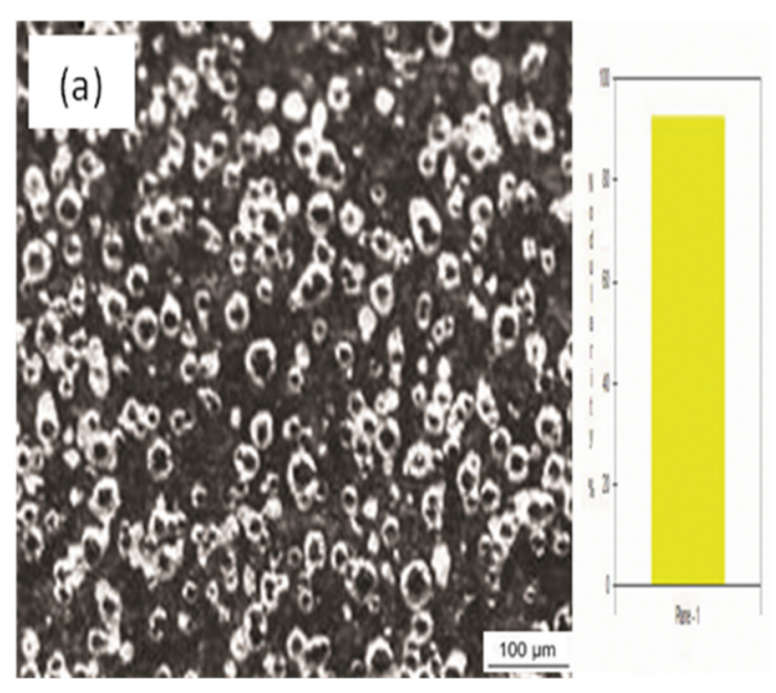

Nodule count 570 (nodule $/ \mathrm{mm}^{2}$ )

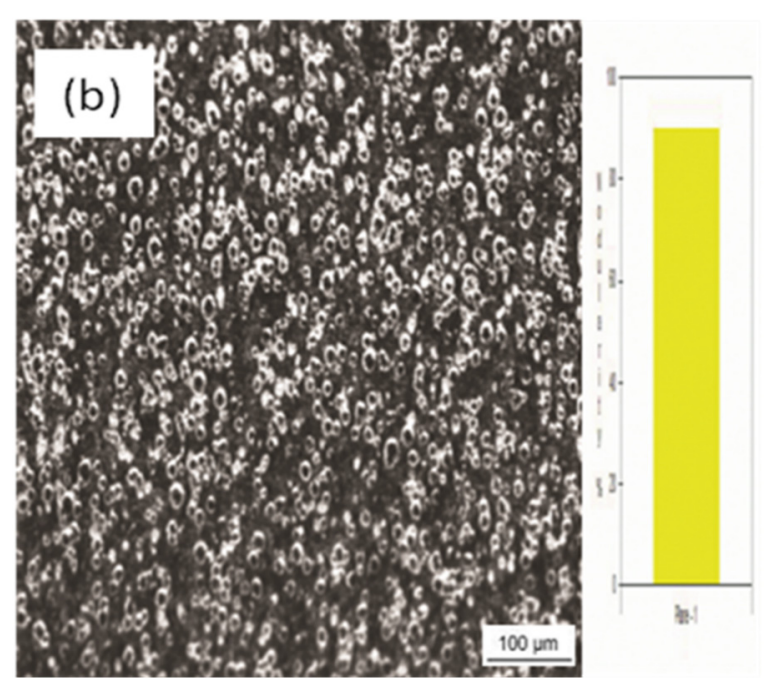

Nodule count 1099 (nodule $/ \mathrm{mm}^{2}$ )

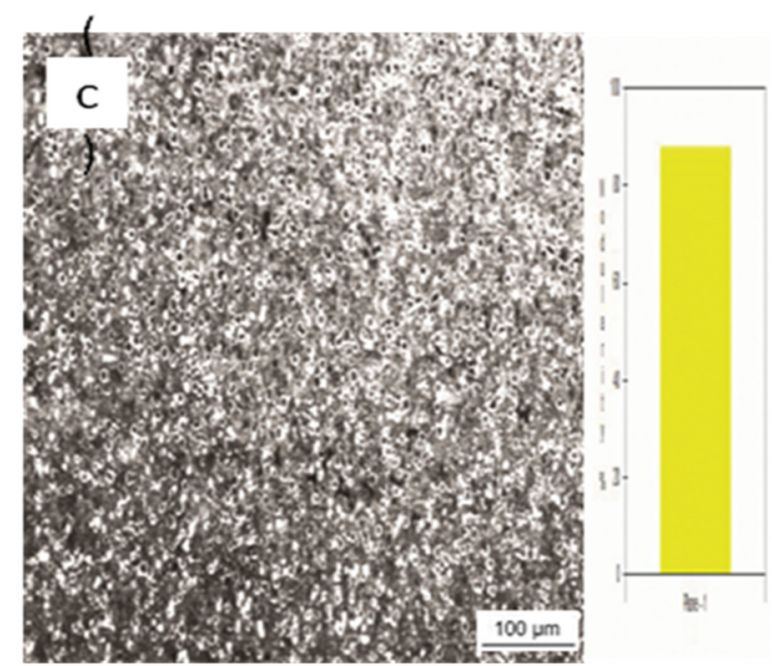

Nodule count 780 (nodule $/ \mathrm{mm}^{2}$ )

Figure 2. $2 \mathrm{~mm}$ section thickness microstructure inoculated by Ce bearing Fe-Si alloy (a) $0.2 \mathrm{wt} \%$ (b) $0.4 \mathrm{wt} \%$ (c) $0.6 \mathrm{wt} \%$ ( one step inoculation)

The $2 \mathrm{~mm}$ section thickness microstrutre inoculated by $\mathrm{Zr}$ bearing $\mathrm{Fe}$-Si alloy representing $0.2 \%, 0.4 \%$ and $0.6 \%$ one step inoculation have been shown in Figure 3.It has been found that Ce bearing $\mathrm{Fe}-\mathrm{Si}$ alloy at $0.4 \mathrm{wt} \%$ (shown in Figure 2) has higher graphite nodularity compare to $\mathrm{Zr}$ bearing Fe-Si alloy at $0.4 \mathrm{wt} \%$ (shown in Figure 3). It has also been found that pearlitic matrix formed and contains concentric shells of ferrite which surrounded by graphite nodules. 


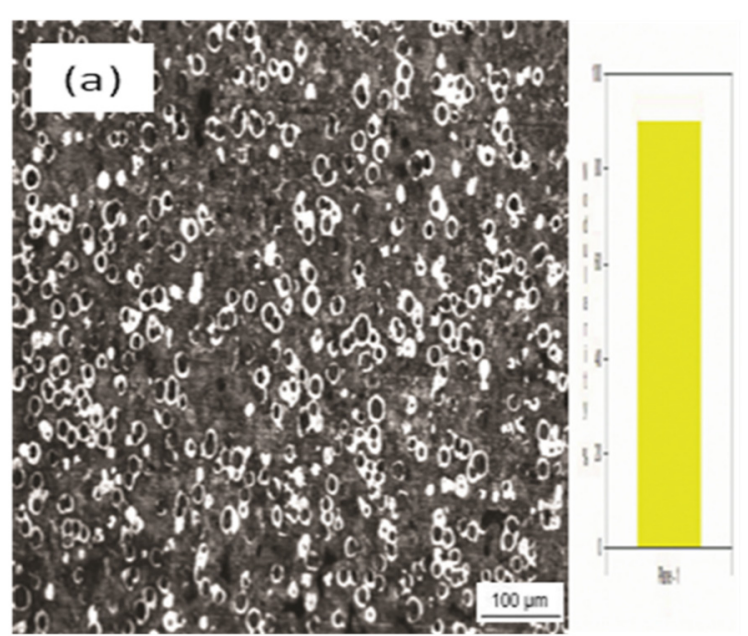

Nodule count $740\left(\right.$ nodule $/ \mathrm{mm}^{2}$ )

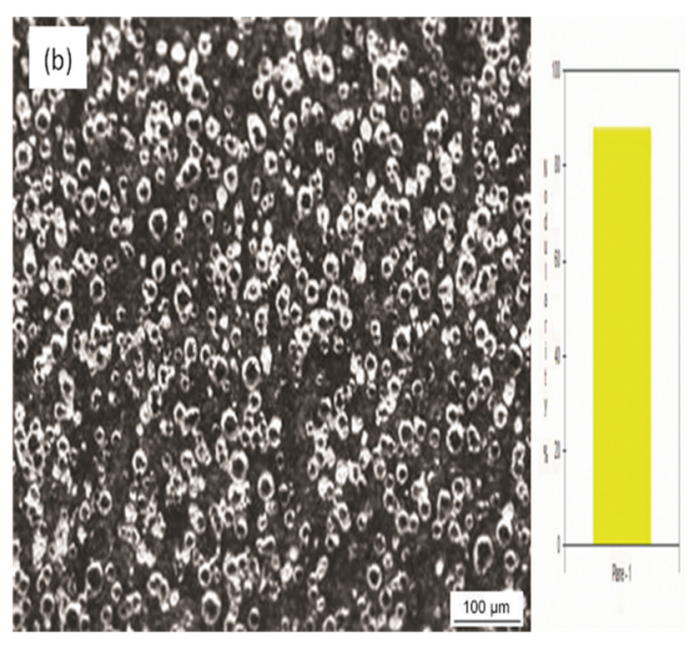

Nodule count 850 (nodule $/ \mathrm{mm}^{2}$ )

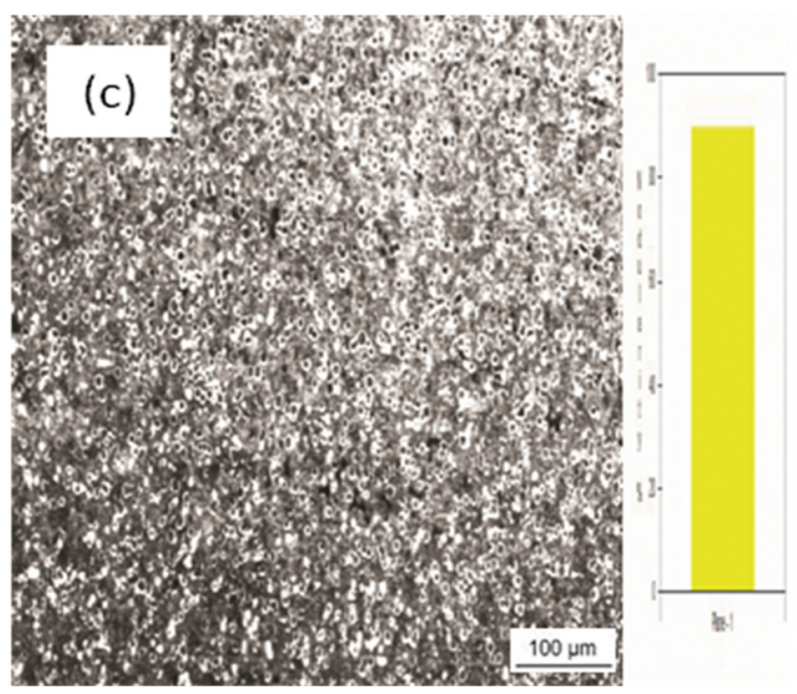

Nodule count $680\left(\right.$ nodule $/ \mathrm{mm}^{2}$ )

Figure $3.2 \mathrm{~mm}$ section thickness microstructure inoculated by $\mathrm{Zr}$ bearing Fe-Si alloy (a) $0.2 \mathrm{wt} \%$ (b) $0.4 \mathrm{wt} \%$ (c) $0.6 \mathrm{wt} \%$ ( one step inoculation)

The $2 \mathrm{~mm}$ section thickness microstrutre inoculated by Sr bearing Fe-Si alloy representing $0.2 \mathrm{wt} \%, 0.4 \mathrm{wt} \%$ and $0.6 \mathrm{wt} \%$ one step inoculation have been shown in Figure 4.It can be seen that one step in mould inoculation at $0.4 \mathrm{wt} \%$, the nodule count $(770$ nodule $/ \mathrm{mm} 2)$ is highest with respect to nodule count ( 650 nodule $/ \mathrm{mm} 2)$ at $0.2 \mathrm{wt} \%$ and nodule count (550 nodule $/ \mathrm{mm} 2)$ at $0.6 \mathrm{wt} \%$ respectively and matrix has been change to pearlitic.

The $2 \mathrm{~mm}$ section thickness of EDS morphology inoculated by (a) Ce bearing Fe-Si alloy (b) $\mathrm{Zr}$ bearing Fe-Si alloy and (c) Sr bearing Fe-Si alloy at $0.4 \mathrm{wt} \%$ one step in mould inoculation have been shown in Figure 5. It has been observed that graphite nodularity of Ce bearing Fe-Si alloy has more than $\mathrm{Zr}$ bearing Fe-Si alloy and $\mathrm{Sr}$ bearing FeSi alloy may due to formation of cerium-calcium-sulphides and oxides during solidification (Riposan, Chisamera, Uta, Stan, Naro, \& Williams, 2014; Ochulor, Adeosun, Amuda, \& Balogun, 2015).

\subsection{Tensile Data}

The $2 \mathrm{~mm}$ section thickness of SEM fractographs inoculated by (a) Ce bearing Fe-Si alloy (b) Zr bearing Fe-Si alloy and (c) Sr bearing Fe-Si alloy at $0.4 \mathrm{wt} \%$ one step in mould inoculation have been shown in Figure 6 . It has been observed that Ce bearing Fe-Si alloy for one step in mould inoculation at $0.4 \mathrm{wt} \%$ contain mainly pearlitic matrix having ultimate tensile strength(UTS) and percentage of elongation are $720 \pm 3 \mathrm{MPa}$ and $4.5 \pm 3 \%$ which are higher than Zr bearing Fe-Si alloy ( UTS and \% elongation are $655 \pm 5 \mathrm{MPa}$ and $3.3 \pm 5 \%$ ) and $\mathrm{Sr}$ bearing Fe-Si alloy (UTS and \% elongation are $557 \pm 5 \mathrm{MPa}$ and $2.3 \pm 5 \%$ ) respectively shown in Table 4. (Riposan, Chisamera, 
Uta, Stan, Naro, \& Williams, 2014; Ochulor, Adeosun, Amuda, \& Balogun, 2015) reported that carbon diffusion towards graphitization centre may due to formation of cerium-calcium-sulphides and oxides so volume fraction of ferrite increases more and volume fraction of pearlite decreases less in Ce bearing Fe-Si alloy.

Table 4. 2 mm section thickness tensile data (a) Ce bearing Fe-Si alloy (b) $\mathrm{Zr}$ bearing Fe-Si alloy (c) $\mathrm{Sr}$ bearing Fe-Si alloy( $0.4 \mathrm{wt} \%$ one step inoculation )

\begin{tabular}{ccccc}
\hline Inoculants & $\begin{array}{c}\text { As-cast } \\
\text { DI }\end{array}$ & $\begin{array}{c}\text { Elongation } \\
(\%)\end{array}$ & $\begin{array}{c}\text { YS } \\
(\mathrm{MPa})\end{array}$ & $\begin{array}{c}\text { UTS } \\
(\mathrm{MPa})\end{array}$ \\
\hline Ce bearing Fe-Si alloy & $2 \mathrm{~mm}$ & $4.5 \pm 3$ & $491 \pm 3$ & $720 \pm 3$ \\
Zr bearing Fe-Si alloy & $2 \mathrm{~mm}$ & $3.3 \pm 5$ & $470 \pm 5$ & $655 \pm 5$ \\
Sr bearing Fe-Si alloy & $2 \mathrm{~mm}$ & $2.3 \pm 5$ & $430 \pm 5$ & $557 \pm 5$ \\
\hline
\end{tabular}

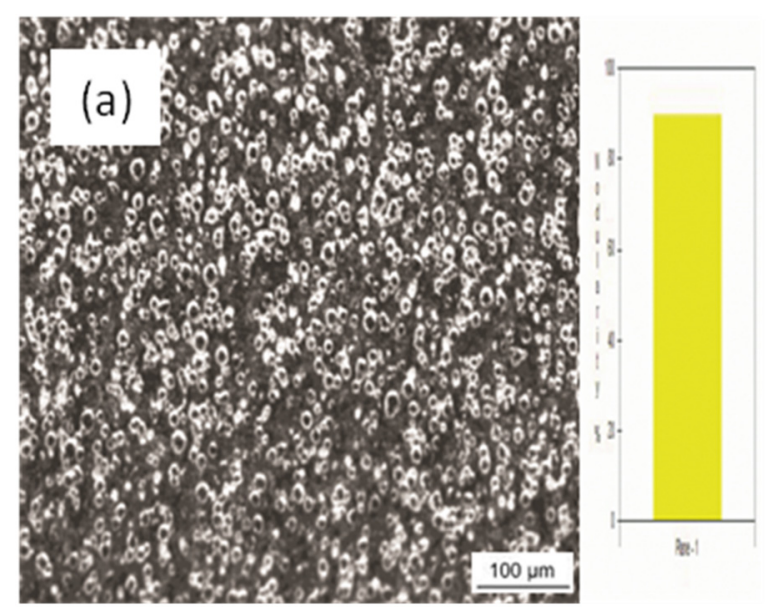

Nodule count $650\left(\right.$ nodule $\left./ \mathrm{mm}^{2}\right)$

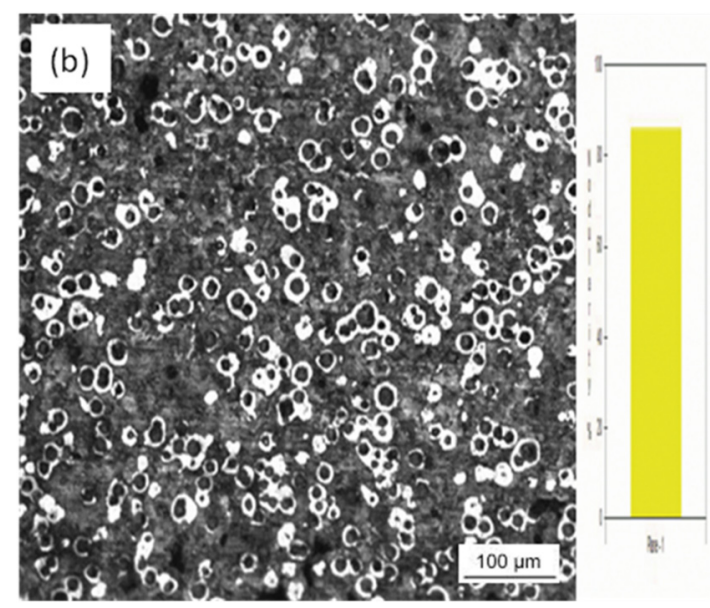

Nodule count $770\left(\right.$ nodule $\left./ \mathrm{mm}^{2}\right)$

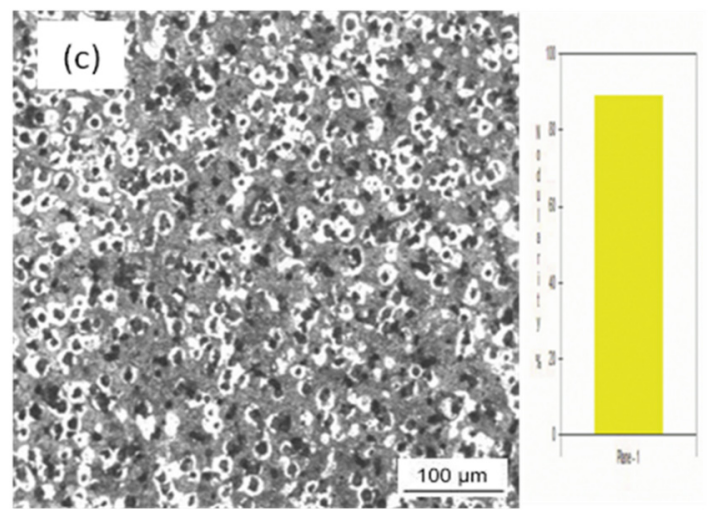

Nodule count 550 (nodule $/ \mathrm{mm}^{2}$ )

Figure $4.2 \mathrm{~mm}$ section thickness microstructure inoculated by Sr bearing Fe-Si alloy (a) $0.2 \mathrm{wt} \%$ (b) $0.4 \mathrm{wt} \%$ (c) $0.6 \mathrm{wt} \%$ (one step inoculation) 

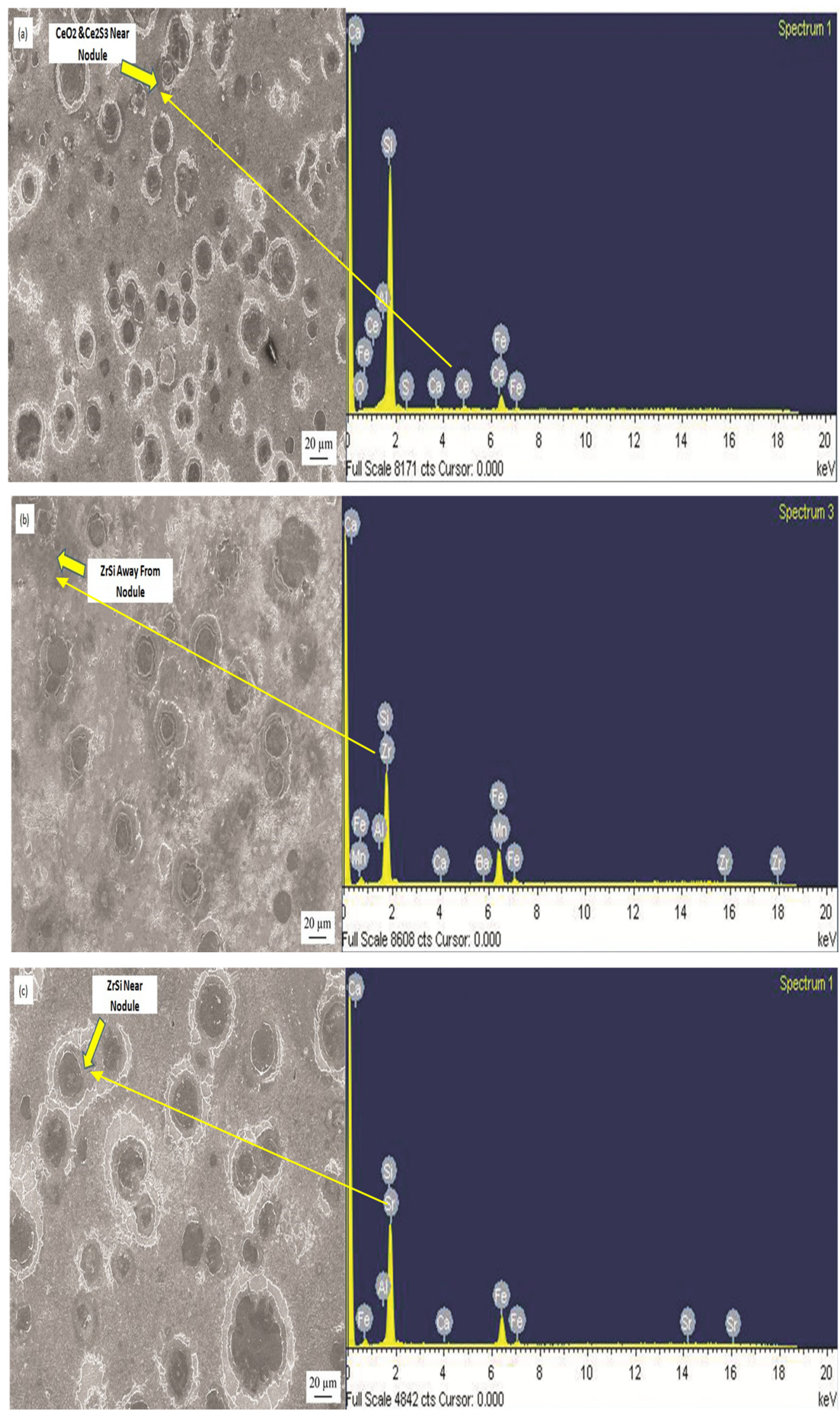

Figure 5. $2 \mathrm{~mm}$ section thickness of SEM with EDS micrograph inoculated by (a) Ce bearing Fe-Si alloy (b) $\mathrm{Zr}$ bearing $\mathrm{Fe}-\mathrm{Si}$ alloy (c) Sr bearing Fe-Si alloy ( $0.4 \mathrm{wt} \%$ one step inoculation) 

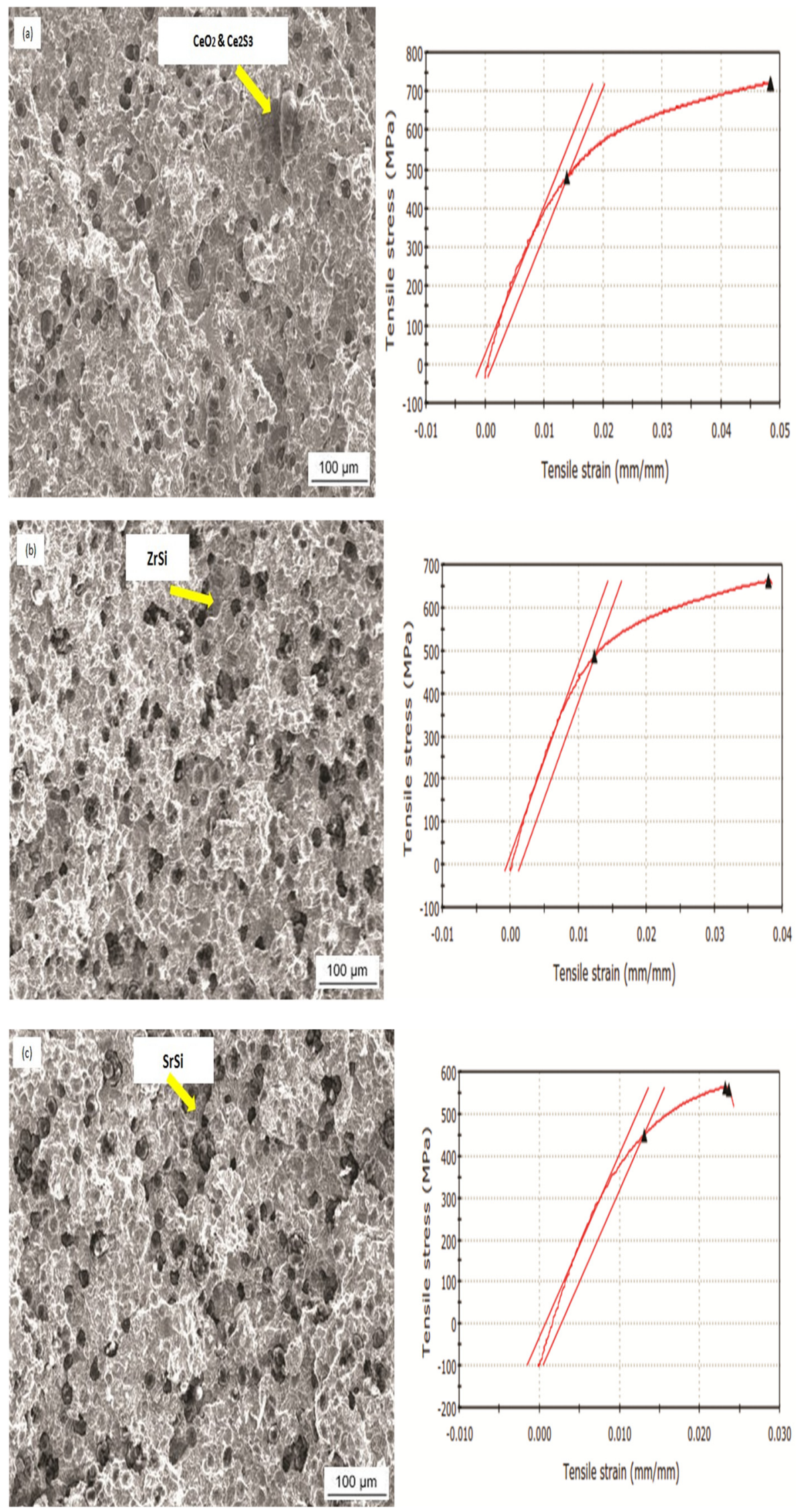

Figure 6. $2 \mathrm{~mm}$ section thickness of Tensile SEM fractograph inoculated by (a) Ce bearing Fe-Si alloy(b) $\mathrm{Zr}$ bearing Fe-Si alloy (c) Sr bearing Fe-Si alloy ( $0.4 \mathrm{wt} \%$ one step inoculation) 


\subsection{Impact Data}

It can be noted from Table 5, impact strength of Ce bearing Fe-Si alloy has higher value compare to $\mathrm{Zr}$ bearing Fe-Si alloy and $\mathrm{Sr}$ bearing Fe-Si alloy at $0.4 \mathrm{wt} \%$ one step in mould inoculation because of pearlite and ferrite volume fraction present in the matrix and also SEM fractographs with $2 \mathrm{~mm}$ section thickness of Ce bearing Fe-Si alloy contains cerium oxide and cerium sulphides present in the matrix near graphite nodule may increases more nuclei during solidification irrespective of $\mathrm{Zr}$ bearing $\mathrm{Fe}-\mathrm{Si}$ alloy and $\mathrm{Sr}$ bearing $\mathrm{Fe}-\mathrm{Si}$ alloy at $0.4 \mathrm{wt} \%$ one step in mould inoculation shown in Figure 7 respectively.

Table $5.2 \mathrm{~mm}$ section thickness impact data (a) Ce bearing Fe-Si alloy (b) $\mathrm{Zr}$ bearing Fe-Si alloy (c) Sr bearing Fe-Si alloy (0.4wt\%one step inoculation)

\begin{tabular}{ccc}
\hline Inoculants & As-cast DIImpact & Strength $\left(\mathrm{J} / \mathrm{cm}^{2}\right)$ \\
\hline Ce bearing Fe-Si alloy & $2 \mathrm{~mm}$ & 75.28 \\
Zr bearing Fe-Si alloy & $2 \mathrm{~mm}$ & 62.32 \\
Sr bearing Fe-Si alloy & $2 \mathrm{~mm}$ & 55.35 \\
\hline
\end{tabular}
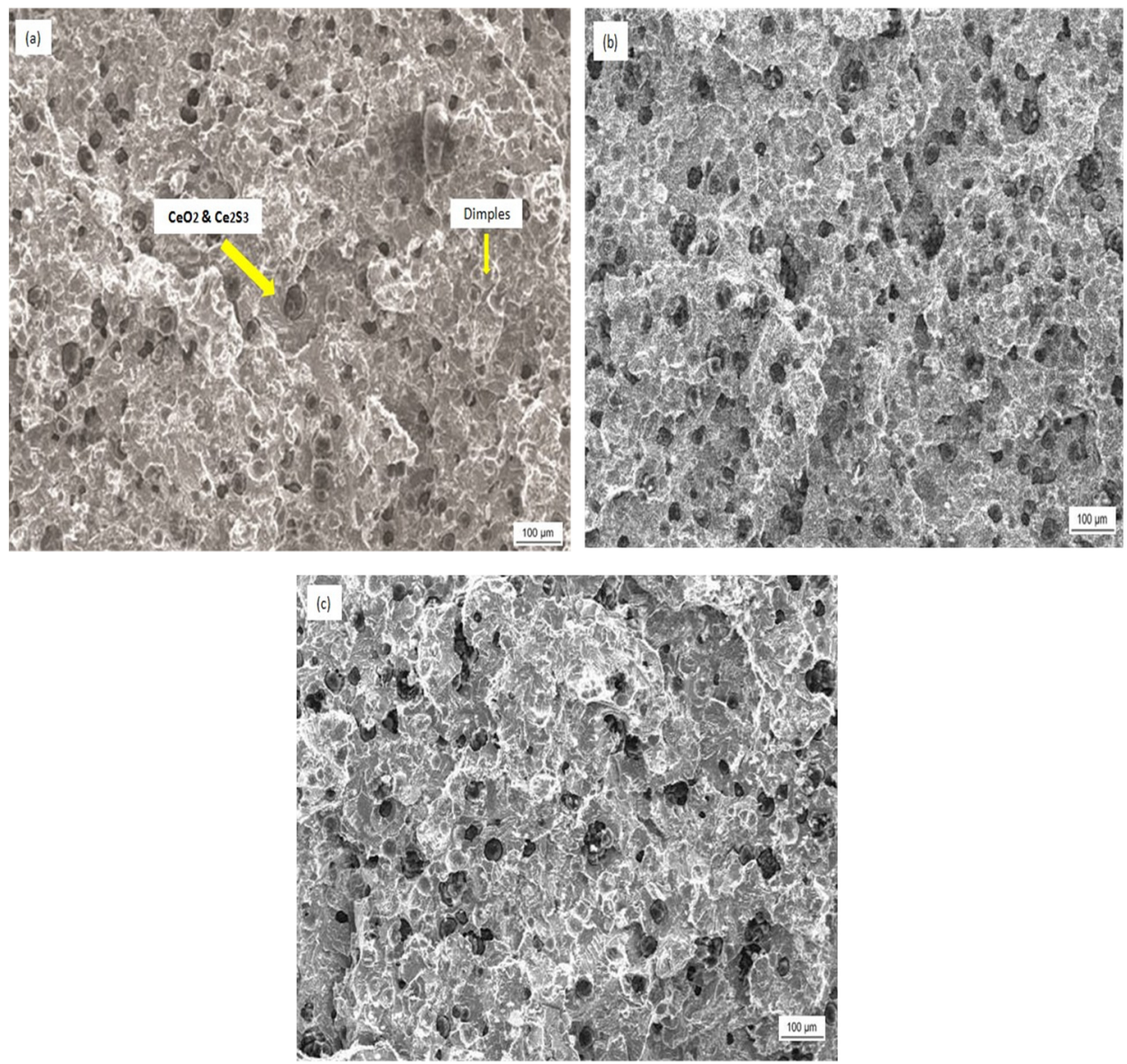

Figure 7. SEM fractograph of $2 \mathrm{~mm}$ impact sample inoculated by (a) Ce bearing Fe-Si alloy (b) $\mathrm{Zr}$ bearing Fe-Si alloy (c) Sr bearing Fe-Si alloy ( $0.4 \mathrm{wt} \%$ one step inoculation)

\section{Conclusions}

Following concluding observations may be drawn from this study.

- The present study very clearly indicate that one step in mould inoculation methodology very potent to incresase the mechanical properties of $2 \mathrm{~mm}$ section thickness of thin casting ,especially with Ce bearing Fe-Si alloy . 
- It has been observed that one step in mould inoculation at $0.4 \mathrm{wt} \%$ contain mainly pearlitic matrix having ultimate tensile strength (UTS) and percentage of elongation are $720 \pm 3 \mathrm{MPa}$ and $4.5 \pm 3 \%$ which are higher than Zr bearing Fe-Si alloy (UTS and \% elongation are $655 \pm 5 \mathrm{MPa}$ and $3.3 \pm 5 \%$ ) and Sr bearing Fe-Si alloy (UTS and \% elongation are $557 \pm 5 \mathrm{MPa}$ and $2.3 \pm 5 \%$ ) respectively.

- It has been observed that wear of $2 \mathrm{~mm}$ section thickness of Ce bearing Fe-Si alloy has greater wear resistance $(272 \mathrm{HV})$ compare to $\mathrm{Zr}$ bearing Fe-Si alloy (262HV) and $\mathrm{Sr}$ bearing Fe-Si alloy (259HV) respectively at $0.4 \mathrm{wt} \%$ one step in mould inoculation.

\section{Acknowledgement}

The authors are thanksful to the Managing Director Mr. Dilip Kumar Gopalka of Hindustan Malleables \& Forging Ltd, Dhanbad for providing the facilities of experiment and valuable comments.

\section{References}

Banerjee, D.K., \& Stefanescu, D.M. (1991). Structure transitions and solidification kinetics of S.G cast iron during directional solidification experiment.AFS Transaction, 99, 747-759.

Chisamera, M., Riposan, I., Stan, S., Toboc, P., Skaland, T., \& White, D. (2013). Shrinkage evaluation in ductile iron as influenced by mould media and inoculant type. International Journal of Cast Metal Research, 24(1), 28-36.

Choi, J.O., Kim, J.Y., Choi, C.O., Kimb, J.K., \& Rohatgi, P.K. (2004). Effect of rare earth element on microstructure formation and mechanical properties of thin wall ductile iron castings. Materials Science and Engineering: A, 383, 323-333.

David, P., Mossone, J., Boeri, R., \& Sikora, J. (2009).Gating system design to cast thin wall ductile iron plates. Foundry Trade Journal, 182, 119-126.

Dix, L.P., Ruxanda, R., Torrance, J., Fukumato, M., \& Stefanescu, D.M. (2003). Static mechanical properties of ferritic and pearlitic lightweight ductile iron castings. AFS Transaction, 111, 1149-1164

Karsay, S. I. (1965). Production of Thin As-Cast Ductile Iron. Modern Castings, 124-133.

Mampaey, F., \& Xu, Z.A. (1997). Mold filling and solidification of a thin-wall ductile iron casting. AFS Transaction, 105, 95-103.

Ochulor, E. F., Adeosun, S.O., Amuda, M. O. H., \& Balogun, S. A. (2015). Strength Characteristics of inoculated and nodularised thin wall ductile iron castings. Journal of Minerals and Materials Characterization and Engineering, 3, 94-105.

Olsen, S.O., \& Skaland, T. (2004). Inoculation of grey and ductile iron. Proceeding of World Foundry Congress, Istanbul, Turkey, World Foundry Organization, 2000.

Riposan, I., Chisamera, M., Uta, V., Stan, S., Naro, R. \& Williams, D. (2014). The Importance of rare earth contribution from nodulizing Alloys and Their Subsequent Effect on the Inoculation of Ductile Iron. International Journal of Metal casting, 8(2), 65-80.

Ruxanda, R.E., Stefanescu, D.M., \& Piwonka, T.S. (2002). Microstructure characterization of Ductile Thin Wall Iron Castings. AFS Transaction, 110, 1131-1247.

Skaland, T. (2001). A new approach to ductile iron inoculation. Transaction American Foundry Society, 28(1), 112.

Upadhyaya, R., Singh, K.K., \& Kumar, R. (2017). Microstructure and Mechanical Properties of thin wall ductile iron. Journal of Automobile Engineering and Applications, 4(2),35-39.

Woolley, J.M., \& Stefanescu, D.M. (2005). Microshrinkage Propensity in Thin wall ductile iron casting. AFS Transaction, 637-643.

Yeunga, C.F., \& Leea, W.B. (1998). The morphology of solidification of thin section ductile iron castings. Material Characterization, 40(5), 201-208.

\section{Copyrights}

Copyright for this article is retained by the author(s), with first publication rights granted to the journal.

This is an open-access article distributed under the terms and conditions of the Creative Commons Attribution license (http://creativecommons.org/licenses/by/4.0/). 